\section{Pengembangan Bahan Ajar Biologi Berbasis Humor Materi Pencemaran Lingkungan Pada SMP Kelas VII}

\author{
Fathur Rahman \\ Nurhayati B \\ Rachmawaty
}

\begin{abstract}
Abstrak. Tujuan dari penelitian ini untuk mengembangkan bahan ajar berbasis humor pada materi pencemaran lingkungan untuk peserta didik SMP kelas VII yang valid dan praktis. Jenis penelitian ini ialah penelitian pengembangan $(R \&$ D). Pengembangan majalah ini menggunanakan model ADDIE. Tahapan ADDIE adalah analisis, desain, pengembangan, implementasi, dan evaluasi. Penilaian majalah ini dievaluasi oleh dua validator ahli. Hasil dari evaluasi komik humor biologi oleh validator ahli menunjukkan bahwa komik humor biologi tersebut bersifat valid dengan nilai 4,49 (valid). Kepraktisan produk yang diperoleh dari respon guru dengan nilai 83\% (praktis) dan respon peserta didik dengan nilai 81\% (praktis). Berdasarkan hasil ini, dapat disimpulkan bahwa pengembangan komik humor biologi pada materi pencemaran lingkungan bersifat valid dan praktis.
\end{abstract}

Kata Kunci: komik,humor, bahan ajar

\section{Pendahuluan}

Proses pembelajaran selama ini umumnya cenderung monoton dan membuat siswa merasa jenuh saat menerima pelajaran, selain itu sering kita jumpai pula siswa yang kurang termotivasi untuk belajar karena media atau bahan ajar yang disediakan oleh guru kurang begitu menarik, sehingga minat siswa untuk belajar menggunakan bahan ajar tersebut kurang, sehingga akan berdampak pada proses dan hasil belajar siswa yang kurang memuaskan (Arifianto dan Salamah, 2010).

Pada Umumnya bahan ajar yang digunakan guru selama ini kurang menarik, kurang komunikatif, dan cenderung membuat siswa cepat bosan. Hal ini menyebabkan siswa kurang berminat untuk membaca bahan ajar yang diberikan oleh gurunya untuk memperleh ilmu pengetahuan baru. Bahan ajar yang digunakan oleh guru seharusnya dapat menunjang siswa untuk lebih termotivasi dan bersemangat untuk belajar serta aktif dalam pembelajaran. Penerapan humor pada bahan ajar yang akan digunakan peserta didik untuk belajar, dapat meningkatkan minat peserta didik untuk menyerap materi pembelajaran dengan baik, karena dengan humor, peserta didik dapat dengan luwes mempelajari tiap materi yang disajikan, sebagaiama yang diketahui, pembelajaran yang disajikan dengan candaan atau bahkan hal lucu, akan membuat memori ingatan menyimpannya lebih lama, dibandingkan pembelajaran atau bahan ajar yang monoton dan biasa-biasa saja (Rahmanadji, 2011). Hasil observasi awal di SMP Negeri 30

\section{Biology Teaching and Learning}

p-ISSN 2621 - 5527

e-ISSN 2621 - 5535

Abstract. The purpose of this study is to develop humor-based teaching materials on environmental pollution material for class VII students who are valid and practical. This type of research is development research $(R \& D)$. The development of this magazine uses the ADDIE model. The ADDIE stage is analysis, design, development implementation and evaluation. This magazine's evaluation was evaluated by two expert validators. The results of the evaluation of biological humor comics by expert validators show that the biology humor comics are valid with a value of 4.49 (valid). The practicality of the product obtained from the teacher's response with a value of $83 \%$ (practical) and the response of students with a value of $81 \%$ (practical). Based on these results, it can be concluded that the development of biological humor comics in environmental pollution material is valid and practical.

Keywords: comics, humor, teaching materials

Fathur Rahman

Universitas Negeri Makassar Indonesia

Nurhayati, B

Universitas Negeri Makassar Indonesia

Rachmawaty

Universitas Negeri Makassar Indonesia 
Makassar bahwa pembelajaran di kelas bersifat monoton dan membosankan, sehingga terkadang siswa acuh tak acuh terhadap penjelasan guru, mengantuk, serta melakukan aktivitas lainnya seperti mengerjakan tugas rumah (PR) ataukah cerita yang lain bersama temantemannya selama pembelajaran berlangsung. Banyak di antara siswa yang mengeluh mengenai pola mengajar guru, isi bahan ajar yang kurang menarik, dan tata bahasanya yang kurang komunikatif sehingga sukar untuk dinalar atau dipahami oleh siswa itu sendir.

Berdasarkan uraian di atas, humor dalam pembelajaran memberi dampak positif terhadap respon peserta didik, maka dari itu pula timbul keinginan peneliti untuk melakukan penelitian yaitu dengan mengembangkan bahan ajar dalam bentuk komik berbasis humor.

\section{Metode Penelitian}

\section{Jenis Penelitian}

Penelitian ini merupakan Research and Development $(R \& D)$ atau merupakan penelitian dan pengembangan dengan menggunakan model ADDIE dimana model ini memiliki lima tahap yaitu Analyze, Design, Develop, Implement, dan evaluate. Pemilihan model ini didasarkan pada pengembangan yang lebih sistematis dan jelas sehingga mudah untuk dilaksanakan dan memudahkan peneliti dalam membuat media pembelajaran yang efektif, efisen dan menarik.

\section{Tempat Penelitian dan Subjek Penelitian}

Tempat pelaksanaan uji coba terbatas yaitu di SMP Negeri 30 Makassar pada Kelas VII. Subjek dalam penelitian ini adalah peserta didik kelas VII di SMP Negeri 30 Makassar yang berjumlah 35 peserta didik yang diberikan angket dan pengenalan bahan ajar berbasis humor.

\section{Instrumen Penelitian}

Instrumen penelitian yang digunakan adalah lembar validasi oleh ahli dan lembar praktisi guru biologi serta angket respon peserta didik. Data penelitian meliputi: data validitas dan data kepraktisan. Uji efektivitas tidak dilaksanakan karena keterbatasan waktu peneliti.

Setelah proses penginputan data dilakukan, data yang diperoleh dari penilaian ahli media dan materi dianalisis. Menurut Sudjana (2007), Untuk menentukan persentase penilaian validator, digunakan rumus:

Keterangan:

$$
P P V=\frac{\Sigma \text { Skor Validator }}{\Sigma \text { Validator } \times \Sigma \text { Item } \times \text { Skala Tertinggi }} \times 100 \%
$$

PPV : Persentase penilaian validator

$\Sigma$ Skor Validator : Jumlah skor yang diberikan kedua validator

$\Sigma$ Validator : Jumlah Validator

$\Sigma$ Item : Jumlah Item yang dinilai

Tabel 1. Kriteria Kevalidan

\begin{tabular}{|c|c|}
\hline Nilai & Keterangan \\
\hline $1 \leq \mathrm{Va}<2$ & Tidak Valid \\
\hline $2 \leq \mathrm{Va}<3$ & Kurang Valid \\
\hline $3 \leq \mathrm{Va}<4$ & Cukup Valid \\
\hline $4 \leq \mathrm{Va} \leq 5$ & Valid \\
\hline $\mathrm{Va}=5$ & Sangat Valid \\
\hline
\end{tabular}

(Sugiyono, 2010).

Keterangan: Va adalah nilai rata-rata kevalidan dari semua validator. 
(hIm. 114-123)

Uji kevalidan suatu instrumen, media dan materi dilakukan oleh 2 validator ahli, dan hasil analisis data dinyatakan dengan mengacu pada kriteria tingkat kevalidan yakni, cukup valid, valid, dan sangat valid, apabila suatu produk memenuhi kriteria tersebut maka dapat dinyatakan produk baik, atau layak untuk digunakan dan diterapkan, dan apabila suatu produk mencapai hasil analisis data berada pada rentang nilai kurang valid dan tidak valid, maka semua produk yang dikembangkan harus diperbaiki kembali atas dasar saran dan masukan setiap validator.

Tabel 2. Skala Tingkat Penilaian Validator Terhadap Media dan Materi

\begin{tabular}{|c|c|}
\hline $\begin{array}{c}\text { Persentase } \\
\text { (\%) }\end{array}$ & Keterangan \\
\hline $70,00-90,00$ & Baik/ Valid/ Layak \\
\hline $50,00-69,99$ & $\begin{array}{c}\text { Cukup Baik/Cukup } \\
\text { Valid/Cukup Layak }\end{array}$ \\
\hline $40,00-49,99$ & $\begin{array}{c}\text { Kurang } \\
\text { Baik/KurangValid/Kurang } \\
\text { Layak }\end{array}$ \\
\hline $0-39,99$ & Tidak Baik (Diganti) \\
\hline
\end{tabular}

Berdasarkan hasil penilaian ditentukan nilai rata-rata yang diberikan kemudian menghitung persentase respon siswa dan respon siswa tiap pertanyaan. Selanjutnya kepraktisan komik humor biologi ditentukan dengan respon guru dan siswa positif atau tidaknya dengan cara mencocokkan hasil persentase kriteria positif (Sugiyono, 2010) pada Tabel 3 di bawah ini:

\section{Tabel 3. Penilaian Item Angket Siswa dan Guru}

\begin{tabular}{|c|c|c|}
\hline Kategori & $\begin{array}{c}\text { Skor Setiap } \\
\text { Pernyataan } \\
\text { negatif }\end{array}$ & $\begin{array}{c}\text { Skor Setiap } \\
\text { Pernyataan } \\
\text { positif }\end{array}$ \\
\hline Sangat Setuju & 1 & 5 \\
\hline Setuju & 2 & 4 \\
\hline Kurang Setuju & 3 & 3 \\
\hline Tidak Setuju & 4 & 2 \\
\hline $\begin{array}{c}\text { Sangat Tidak } \\
\text { Setuju }\end{array}$ & 5 & 1 \\
\hline
\end{tabular}

Uji kepraktisan berbasis proyek dinilai dari hasil penilaian angket respon guru dan siswa. Guru akan menguji kepraktisan bahan ajar yang dikembangkan sedangkan siswa akan menguji kepraktisan bahan ajar yang dikembangkan. Uji kepraktisan dilakukan dengan tujuan untuk menguji produk pengembangan telah praktis dan mudah digunakan atau sebaliknya. Untuk mengukur tingkat kepraktisan produk pengembangan, digunakan teknik analisis sebagai berikut.

Keterangan:

$$
\mathrm{P}=\frac{\sum_{i=1}^{5} x_{i}}{\sum_{j=1}^{5} x_{j}} \times 100 \%
$$

P : presentase pilihan

$x_{i} \quad$ : skor jawaban penilaian oleh ahli (guru dan/ peserta didik)

$x_{j} \quad$ : jumlah skor jawaban tertinggi 
Setelah menghitung presentase penilaian guru, kemudian menentukan kriteria respon yang telah diberikan terhadap presentase hasil analisis kepraktisan berdasarkan pedoman penilaian kepraktisan produk pengembangan seperti yang ditunjukkan pada Tabel 4

Tabel 4. Pedoman Penilaian Kepraktisan Produk Pengemba
\begin{tabular}{|c|c|c|}
\hline Persentase (\%) & $\begin{array}{c}\text { Kriteria } \\
\text { Kepraktisan }\end{array}$ & Keterangan \\
\hline $\mathbf{8 0 - 1 0 0}$ & Sangat praktis & Tidak revisi \\
\hline $\mathbf{6 6 - 7 9}$ & Praktis & Tidak revisi \\
\hline $\mathbf{5 5}-\mathbf{6 5}$ & Cukup praktis & Tidak revisi \\
\hline $\mathbf{4 0 - 5 5}$ & Kurang praktis & Revisi \\
\hline $\mathbf{3 0 - 3 9}$ & Tidak praktis & Revisi \\
\hline
\end{tabular}

(Sumber: Arikunto, 2016).

Bahan ajar yang dikembangkan memiliki derajat kepraktisan yang baik, jika minimal kriteria kepraktisan yang dicapai adalah kriteria praktis dengan keterangan tidak revisi.

\section{Hasil Penelitian}

Penelitian pengembangan bahan ajar berbasis humor materi pencemaran lingkungan ini merupakan penelitian pengembangan yang mengacu pada model pengembangan ADDIE. Penelitian ini dilakukan sampai tahap implementasi (implement) dan satu tahapan tidak dilakukan yaitu evaluasi (evaluation) karena keterbatasan waktu.

\section{Hasil Penelitian}

Penelitian pengembangan yang dilakukan menghasilkan produk berupa bahan berbasis humor yang valid dan praktis. Adapun hasil analisis uji validitas dan kepraktisan produk sebagai berikut.

\section{Uji Validitas}

Validasi dilakukan beberapa kali hingga diperoleh perangkat bahan ajar yang bersifat valid dan praktis sehingga layak digunakan dalam proses pembelajaran. Adapun hasil dari penilaian Validator ahli terhadap bahan ajar berbasis humor sebagai berikut.

\section{1) Uji Kevalidan Lembar Instrumen Penilaian}

Tabel 5. Analisis Data Uji Kevalidan Lembar Instrumen Penilaian Validator

\begin{tabular}{|c|c|c|c|c|c|}
\hline No & $\begin{array}{c}\text { Aspek yang } \\
\text { dinilai }\end{array}$ & V1 & V2 & $\begin{array}{c}\text { Skor rata- } \\
\text { rata }\left(\boldsymbol{A}_{\boldsymbol{i}}\right)\end{array}$ & Ket. \\
\hline I & $\begin{array}{c}\text { Aspek } \\
\text { Petunjuk }\end{array}$ & 4,0 & 5,0 & 4,5 & Valid \\
\hline II & Aspek Isi & 3,6 & 4,3 & 3,95 & $\begin{array}{c}\text { Cukup } \\
\text { Valid }\end{array}$ \\
\hline III & $\begin{array}{c}\text { Aspek } \\
\text { Bahasa }\end{array}$ & 5,0 & 5,0 & 5,0 & $\begin{array}{c}\text { Sangat } \\
\text { Valid }\end{array}$ \\
\hline $\begin{array}{l}\text { Rata-rata } \\
\text { keseluruhan }\end{array}$ & & & $\mathbf{4 , 4 9}$ & Valid \\
\hline
\end{tabular}

Berdasarkaan Tabel 5 dapat dilihat bahwa hasil penilaian validator terhadap lembar instrumen penelitian untuk masing-masing kriteria berada pada kategori, cukup valid, valid dan sangat valid. Sementara untuk rata-rata penilaian secara keseluruhan yakni skor 4,49 
(hlm. 114-123)

dengan keterangan "valid". Merujuk pada tingkat kategori oleh sugiyono, rentang penilaian berada pada $4 \leq \mathrm{Va} \leq 5$, sehingga dapat disimpulkan bahwa instrumen tersebut bersifat valid.

\section{2) Uji Kevalidan Media Sumber Belajar Komik Humor Biologi}

Berikut analisis data kevalidan media sumber belajar komik humor biologi pada Tabel 6.

\section{Tabel 6. Skala Persentase Penilaian Media ke Dua Validator}

\begin{tabular}{|c|c|c|c|c|c|}
\hline \multirow[t]{2}{*}{ No } & \multirow[t]{2}{*}{ Kriteria } & \multicolumn{2}{|c|}{ Persentase } & \multirow{2}{*}{$\begin{array}{c}\text { Rata- } \\
\text { rata } \\
\%\end{array}$} & \multirow[t]{2}{*}{ Ket. } \\
\hline & & I & II & & \\
\hline 1 & $\begin{array}{l}\text { Komposisi } \\
\text { Penul-isan }\end{array}$ & $67 \%$ & $\begin{array}{c}100 \\
\%\end{array}$ & $83 \%$ & $\begin{array}{l}\text { Baik / } \\
\text { Valid }\end{array}$ \\
\hline 2 & Tampilan & $70 \%$ & $85 \%$ & $77 \%$ & $\begin{array}{l}\text { Baik / } \\
\text { Valid }\end{array}$ \\
\hline 3 & Kelayakan & $80 \%$ & $93 \%$ & $87 \%$ & $\begin{array}{l}\text { Baik / } \\
\text { Valid }\end{array}$ \\
\hline \multicolumn{4}{|c|}{ Rata-rata Keseluruha } & $82 \%$ & $\begin{array}{l}\text { Baik / } \\
\text { Valid }\end{array}$ \\
\hline
\end{tabular}

Berdasarkan hasil persentase media dari dua validator pada Tabel 2 terdapat tiga kriteria penilaian yang masing-masing mewakili setiap pernyataan yang diberikan dalam instrumen penilaian media, yaitu komposisi penulisan $83 \%$, tampilan $77 \%$ dan Kelayakan media $87 \%$, sedangkan untuk nilai rata-rata persentase keseluruhan yaitu $82 \%$ dengan keterangan kategori valid, hal ini berdasarkan skala penelitian validator oleh Ridwan (2010) yaitu ketika mencapai $70 \%$ - $90 \%$ maka media tergolong baik/valid, dan tidak perlu direvisi ulang.

\section{3) Uji Kevalidan Materi}

Hasil analisis data dari uji kevalidan materi pada media komik humor biologi yang dilakukan oleh validator ahli maka dapat dilihat pada Tabel 7

Tabel 7. Skala Persentase Penilaian Materi ke Dua Validator

\begin{tabular}{|c|c|c|c|c|c|}
\hline \multirow{2}{*}{ No } & Kriteria & \multicolumn{2}{|c|}{ Persentase } & $\begin{array}{c}\text { Rata- } \\
\text { rata } \\
\text { \% }\end{array}$ & Keterangan \\
\cline { 2 - 5 } & I & II & Baik / Valid \\
\hline 1 & Penyajian materi & $75 \%$ & $85 \%$ & $80 \%$ & Baik / Valid \\
\hline 2 & Kebahasaan & $73 \%$ & $87 \%$ & $80 \%$ & Baik / Valid \\
\hline 3 & $\begin{array}{c}\text { Kesesuaian tingkat } \\
\text { berpikir siswa }\end{array}$ & $73 \%$ & $93 \%$ & $83 \%$ & Baik / Valid \\
\hline
\end{tabular}

Berdasarkan hasil validasi oleh kedua validator materi, maka ditentukan skala persentase penilaian materi, dengan masing-masing kriteria penilaian yaitu penyajian materi 80\%, kebahasaan $80 \%$ dan kesesuaian tingkat berpikir siswa $83 \%$, maka untuk rata-rata keseluruhan persentase mencapai $81 \%$ dengan rentang penilaian 70\% - 90\% sehingga hasil validasi materi dinyatakan baik/valid.

\section{Uji Kepraktisan}

Uji kepraktisan dilakukan oleh guru sebagai praktisi melalui angket respon guru dan angket respon peserta didik. Guru yang memberikan respon yaitu guru mata pelajaran IPA biologi SMPN 30 Makassar 1 Orang, sedangkan peserta didik yang memberikan respon sebanyak 35 orang. Adapun hasil penilaian diuraikan dalam Tabel 8 dan 9. 


\section{Respon Guru}

Tabel 8. Hasil Analisis Data Respon Guru

\begin{tabular}{|c|c|c|c|}
\hline No & Indikator & $\begin{array}{c}\text { Persentase } \\
\text { Indikator } \\
(\mathbf{\%})\end{array}$ & Ket. \\
\hline 1 & Kemanfaatan & 88 & $\begin{array}{c}\text { Sangat } \\
\text { Positif }\end{array}$ \\
\hline 2 & Tampilan & 80 & Positif \\
\hline 3 & Interaksi & 83 & Positif \\
\hline 4 & Kepuasan & 80 & Positif \\
\hline \multicolumn{2}{|c|}{$\begin{array}{c}\text { Skor Penilaian } \\
\text { Keseluruhan }\end{array}$} & $\mathbf{8 3} \%$ & Positif \\
\hline
\end{tabular}

Instrumen tersebut mengacu pada skala penilaian likert five point dengan kriteria penilaian: 5 (sangat setuju), 4 (setuju), 3 (kurang setuju), 2 (tidak setuju), 1 (sangat tidak setuju). Berdasarkan Tabel 3, menunjukkan bahwa hasil respon guru terhadap media komik humor biologi termasuk dalam kategori positif dengan rata-rata keseluruhan persentase yaitu $83 \%$ dengan melihat kategori kepraktisan $70 \% \leq \mathrm{RS}<85 \%$, dapat dinyatakan bahwa media komik humor biologi bersifat praktis jika ditinjau dari respon guru.

\section{Respon Siswa}

\section{Tabel 9. Hasil Analisis Data Respon Siswa}

\begin{tabular}{|c|c|c|c|}
\hline No & $\begin{array}{c}\text { Indikator } \\
\text { Pernyataan }\end{array}$ & $\begin{array}{c}\text { Persentase } \\
\text { Indikator } \\
\text { (\%) }\end{array}$ & Ket. \\
\hline 1 & Kemanfaatan & 82.1 & Positif \\
\hline 2 & Tampilan & 81.8 & Positif \\
\hline 3 & Interaksi & 78.2 & Positif \\
\hline 4 & $\begin{array}{c}\text { Belajar } \\
\text { mandiri }\end{array}$ & 83.7 & Positif \\
\hline \multicolumn{2}{|c|}{$\begin{array}{c}\text { Skor Penilaian } \\
\text { Keseluruhan }\end{array}$} & $\mathbf{8 1} \%$ & Positif \\
\hline
\end{tabular}

Pada instrumen tersebut mengacu pada skala penilaian likert five-point dengan kriteria penilaian: 4 (sangat setuju), 3 (setuju), 2 (tidak setuju), 1 (sangat tidak setuju). Tabel 3 menunjukkan bahwa hasil instrumen respon siswa terhadap komik humor biologi termasuk dalam kategori positif dengan rata-rata keseluruhan persentase yaitu $81 \%$ dengan melihat kategori kepraktisan $70 \% \leq \mathrm{RS}<85 \%$, sehingga dapat dinyatakan bahwa komik humor biologi bersifat praktis.

\section{Pembahasan}

Penggunaan media pembelajaran dapat membangkitkan minat, motivasi dan rangsangan dalam proses pembelajaran, sehingga sangat membantu dalam penyampaian pesan kepada siswa pada saat proses pembelajaran (Wiratmojo, dan Sasonohardjo, 2002). 
Penelitian ini bertujuan mengembangkan media sebagai sumber belajar komik humor biologi valid dan praktis. Media pembelajaran ini bersifat interaktif karena dalam proses pembelajaran ini melibatkan antara guru dan siswa melakukan komunikasi dua arah secara aktif selama proses pembelajaran. Tanpa media, seorang guru cenderung berbicara satu arah kepada muridnya. Namun dengan media guru dapat mengatur kelas sehingga tidak hanya guru sendiri yang aktif tetapi juga mampu mengaktifkan siswa.

Pengembangan komik humor biologi sebagai sumber belajar siswa ini mengacu pada model ADDIE. Tahap analisis, media yang dikembangkan adalah komik humor biologi untuk kelas VII emester genap SMP/MTs materi pencemaran lingkungan. Analisis kebutuhan siswa terhadap media dalam pembelajaran, berdasarkan hasil observasi di lapangan bahwa pemberian media pembelajaran sangat jarang dan bahkan tidak pernah diberikan media pembelajaran pada saat proses pembelajaran, sedangkan kebutuhan siswa akan metode pembelajaran yang bervariasi sangat diperlukan dalam hal ini pemberian media dalam pembelajaran, untuk membangkitkan motivasi belajar dan proses pembelajaran aktif.

Pengembangan media komik humor biologi terdapat beberapa yang perlu diperhatikan, mulai dari kesesuaian materi dengan produk yang akan dibuat, pemilihan software (aplikasi) yang akan digunakan, pemilihan gambar kualitas HD, serta pemilihan warna/layout desain media sangat menentukan. Pemilihan warna background dalam pembuatan komik ini perlu diperhatikan karena turut menentukan kelayakan sebuah produk untuk menghasilkan ketertarikan terhadap suatu media sehingga menentukan kelayakan media itu sendiri. Sebagaimana yang telah dikemukakan oleh Purnama (2011), bahwa penggunaan warna yang sesuai dalam suatu produk media pembelajaran dapat membangkitkan motivasi, perasaan, perhatian, dan kesediaan siswa dalam belajar.

Sebelum dilakukan validasi media terlebih dahulu dilakukan validasi terhadap instrumen penilaian. Penilaian instrumen bertujuan untuk menilai kelayakan instrumen penilaian. Menurut Arikunto (2010) Validitas adalah tingkat kevalidan suatu instrumen, instrumen yang valid adalah instrumen yang mampu mengukur apa yang seharusnya diukur, suatu instrumen yang valid atau sahih mempuyai validitas yang tinggi. Sebaliknya, instrumen kurang valid berarti memiliki validitas yang rendah. uji kevalidan bertujuan untuk melihat kekurangan media pembelajaran, seperti lembar instrumen yang akan digunakan, konten media, serta materi yang disajikan.

Instrumen yang digunakan dalam pengembangan media interaktif ini terdiri atas instrumen penilaian media, instrumen penilaian materi, instrumen respon guru dan instrumen respon siswa. Keempat instrumen tersebut dijabarkan kedalam beberapa pertanyaan positif dan negatif. Hal ini sejalan dan pendapat Widoyoko (2012) variasi antara pertanyaan positif dan negatif dilakukan agar responden betul-betul cermat dalam membaca setiap pernyataan pada instrumen penilaian sehingga responden tidak terkesan asal mengisi angket.

Merujuk pada hasil validasi instrumen penilaian pada Tabel 5 dengan skor keseluruhan validator pertama dengan nilai 4.2 dengan kategori valid dan pada Tabel 6 penilaian validator kedua dengan nilai keseluruhan yaitu 4.7 dengan kategori valid hal ini merujuk pada rentang kategori $(4 \leq \mathrm{Va}<5)$ sehingga dapat disimpulkan instrumen penilaian penelitian bersifat valid. sejalan dengan pendapat dari Nieveen (1999) bahwa suatu media dikatakan baik jika memenuhi aspek-aspek kualitas, yaitu 1) validitas (validity), 2) Kepraktisan (practicaly), dan Keefektifan (effectiveness).

Validasi media pembelajaran dilakukan oleh validator dari jurusan biologi FMIPA UNM, hasil validasi media pembelajaran bertujuan untuk menilai kelayakan dari media yang dikembangkan, pernyataan dalam lembar validasi terdiri dari 10 pernyataan, yang terdiri dari 3 aspek penilaian kevalidan secara garis besar yaitu komposisi penulisan, tampilan, kelayakan fitur tambahan. Hasil validasi dari kedua validator yakni $82 \%$ dengan kategori valid. Menurut Suherman (2009), pembelajaran menggunakan media akan lebih menarik perhatian siswa, kejelasan dan daya tarik gambar menimbulkan rasa keingintahuan siswa lebih tinggi, hal yang menunjukkan bahwa media memiliki aspek motivasi dan meningkatkan minat. 
Melihat dari hasil penilaian validator media dengan skor penilaian yang tidak mencapai angka maksimum 100\%, maka terdapat beberapa kekurangan yang harus tingkatkan lagi dalam penelitian selanjutnya, yakni dilihat dari segi penilaian tampilan media perlu ada perbaikan dalam hal ini isi komik humor biologi yang perlu disajikan lebih menarik lagi menggunakan warna yang lebih menarik. Menurut Purnama (2011), setiap warna memiliki kekuatan-kekuatan di dalamnya. Pemilihan warna yang baik dalam mendesain produk pembelajaran dapat turut membangkitkan dan menstimulir pikiran, perasaan, perhatian dan kemauan siswa. Oleh karena itu tidak setiap warna bisa dipilih begitu saja tanpa mempertimbangkan audiens (siswa). Aspek komposisi penulisan, dalam hal ini komposisi teks masih lebih dominan dibandingkan gambar komik yang edukatif sehingga perlu adanya perbaikan lebih lanjut.

Validasi materi dilakukan untuk melihat kevalidan yang disajikan dalam media pembelajaran, terdiri dari 3 aspek kriteria penilaian yaitu penyajian materi, kebahasaan, dan kesesuaian tingkat berpikir siswa, skor rata-rata persentase keseluruhan penilaian validator yaitu 81\% dengan rentang persentase yakni (70\%-90\%) dengan kategori valid. Penggunaan media sebagai bagian integral pembelajaran di kelas menunjukkan hal positif, seperti pencapaian materi baku, siswa melihat dan membaca penyajian melalui media menerima pesan yang sama meskipun guru menafsirkan isi pelajaran dengan cara berbeda-beda, materi lebih terorganisasikan dengan baik, spesifik dan jelas (Suherman, 2009).

Penyajian materi dengan kategori valid namun dalam penilaian tidak mencapai nilai maksimum yakni $100 \%$, dengan melihat beberapa yang harus ditingkatkan, dalam hal ini aspek materi yang disajikan dalam komik humor biologi yaitu kurangnya kalimat atau info menarik yang berhubungan dengan materi yang disajikan, sehingga belum menjadi perhatian penuh oleh siswa, pada dasarnya suatu komik humor merupakan media yang menyajikan suatu informasi yang lugas yang disajikan secara jelas dan menarik, dan lebih banyak menggunakan bahasa yang persuasif untuk pembaca. Beberapa cara digunakan untuk menarik perhatian pada media berbasis teks adalah warna, huruf dan kotak, warna digunakan sebagai alat penuntun dan penarik perhatian informasi yang penting, memberikan penekanan-penekanan terhadap setiap kata yang dianggap penting (Suherman, 2009).

Kepraktisan media pembelajaran komik humor biologi dapat dilihat dari respon guru dan respon siswa, berdasarkan hasil analisis data penelitian maka ada beberapa kriteria pada instrumen yang diberikan pada respon guru dan siswa, Aspek penilaian terhadap guru yaitu kemanfaatan media, tampilan, interaksi, dan kepuasan. Maka diperoleh hasil analisis data deskriptif instrumen respon guru yaitu kemanfaatan media memperoleh respon sangat positif dengan persentase $88 \%$, tampilan media memperoleh respon positif dengan persentase $80 \%$, interaksi penggunaan media memperoleh respon positif dengan persentase $83 \%$ dan kepuasan dari media memperoleh respon positif dengan persentase $80 \%$, dengan akhir rata-rata persentase yang diperoleh secara keseluruhan dari respon guru yakni $83 \%$ dengan mengacu pada skala rentang penilaian persentase $(70 \%-90 \%)$ dengan rata-rata persentase indikator dari hasil analisis data respon guru bersifat praktis.

Uji kepraktisan guru dalam penggunaan media, dengan adanya media guru menyampaikan informasi lebih jelas dan tepat, dapat ditanggapi dan dimengerti oleh siswa secara cepat dan jelas, guru dapat menggunakan media tanpa perlu menjelaskan mulai dari awal karena media telah dilengkapi dengan beberapa fitur tambahan seperti gambar cerita yang mempermudah aktivitas pembelajaran di kelas, sehingga guru dapat mengefisien waktu pembelajaran. Menurut Suherman (2009), media mampu menyajikan materi secara baik dan jelas, pembelajaran menjadi lebih interaktif dengan melibatkan partisipasi, umpan balik dan penguatan siswa dalam pembelajaran, memperlukan waktu yang singkat dalam mengantarkan pesan-pesan dan isi pembelajaran, sehingga beban guru dalam menjelaskan berulang-berulang mengenai materi hilang dan memusatkan perhatian siswa kepada aspek penting lain dalam proses mengajar. 
Setelah memperoleh persentase (\%) penilaian guru yang dengan skor 83\% dengan kategori positif, namun dapat dilihat bahwa hasil penilaian tersebut tidak mencapai hasil maksimal yakni mencapai 100\% dari kepraktisan media yang diberikan, hal ini dapat dilihat dari beberapa faktor seperti faktor usia dan kondisi guru, yang dimana guru yang berada di sekolah tempat melakukan penelitian. Dimana media seperti komik humor biologi jarang bahkan tak pernah ditemui dalam pembelajaran.

Hasil analisis uji respon siswa yang telah dilakukan, yang terdiri 4 indikator pernyataan yaitu, kemanfaatan media, tampilan, interaksi, dan belajar mandiri. Maka diperoleh hasil analisis data deskriptif instrumen respon siswa yaitu kemanfaatan media memperoleh respon positif dengan persentase 82,1\%, tampilan media memperoleh respon positif dengan persentase $81,8 \%$, interaksi penggunaan media memperoleh respon positif dengan persentase $78,2 \%$ dan belajar mandiri dari media memperoleh respon positif dengan persentase $83,7 \%$. Diperoleh rata-rata persentase untuk respon siswa yakni $81 \%$ dengan keterangan $70 \% \leq \mathrm{RS}<$ $85 \%$ nilai berada pada kategori positif atau media tergolong praktis. Hal senada yang dikemukakan Yamasari (2010) media pembelajaran dinyatakan praktis apabila praktis secara praktik yaitu persentase respon siswa dan respon guru terhadap media menunjukkan dalam kategori positif. Dalam hal ini kepraktisan media berdasarkan respon siswa terlihat dari proses belajar mandiri, artinya siswa melihat media komik humor biologi mampu menjelaskan setiap penjelasan materi yang dikonsep dalam bentuk menarik ini, siswa merasa senang saat belajar dan tidak bosan saat membaca materi pelajaran, buku komik yang didesain simple bias dibawa kemana-mana, dibaca di manapun sehingga memudahkan penggunanya.

Berdasarkan hasil penilaian respon siswa yang dapat di kategorikan praktis namun dalam penilaian ini tidak mencapai hasil maksimal yakni $100 \%$ dapat dilihat dari beberapa faktor yang ada, kurangnya informasi unik dan terbaharui menjadi salah satu penyebab siswa tidak memberikan perhatian penuh terhadap media yang diberikan. Titik fokus penilaian dalam media ini yakni kemandirian belajar siswa, dalam hasil penilaian respon siswa dapat dikategorikan baik, hal ini terjadi karena didalam media yang dikembangkan terdiri dari rentetan cerita bergambar dan materi dikemas dalam bentuk menarik, sehingga siswa merasa senang serta mampu mengatasi kesulitan dalam memahami materi dan menjadi poin baik dalam media ini dalam hal kemandirian belajar. Menurut Triyanto (2010), pada dasarnya, nilai utama dari humor di dalam kelas adalah untuk "merangsang, menggambarkan, memotivasi, dan meredakan ketegangan". Suasana kelas yang menyenangkan dengan humor mengurangi stres yang dialami siswa dan meningkatkan kreativitas dan imajinasi yang lebih besar dan memberikan kontribusi ke sikap positif dan kondusif untuk belajar.

Mengembangkan media komik humor biologi dapat dilakukan pada materi-materi lainnya agar menjadi lebih bervariasi dan lebih memudahkan siswa dalam memahami materi pelajaran secara mandiri, serta diharapkan untuk penelitian lanjutan dari media ini yakni untuk melakukan uji keefektifan media komik humor biologi sebagai sumber belajar biologi kepada siswa, ini belum dilakukan oleh karena itu nantinya dapat menyempurnakan penelitian ini. Menurut Nieveen (1999) bahwa suatu media dikatakan baik jika memenuhi aspek-aspek kualitas agar memperoleh produk pemgembangan yang baik, yaitu 1) validitas (validity), 2) Kepraktisan (practicaly), dan Keefektifan (effectiveness).

\section{Kesimpulan}

Berdasarkan hasil penelitian dan pembahasan, maka dapat disimpulkan bahwa Pengembangan bahan ajar biologi berbasis humor pada materi pencemaran lingkungan untuk kelas VII SMP/MTs bersifat valid. Analisis data rata-rata skor validitas yang diperoleh yaitu 82\% termasuk dalam kategori valid $\left(70 \% \leq \mathrm{V}_{\mathrm{a}}<90 \%\right)$. Pengembangan bahan ajar biologi berbasis humor pada materi pencemaran lingkungan untuk kelas VII SMP/MTs bersifat praktis. Hasil Analisis data angket respon guru sebesar $83 \%$ dan persentase rata-rata respon peserta didik 
sebesar $81 \%$. Sehingga keduanya termasuk dalam kategori kepraktisan $70 \% \leq \mathrm{R}_{s} \leq 85 \%$ dengan kriteria sangat praktis tanpa revisi.

\section{Referensi}

Arifianto, Rofiq, A \& Salamah. (2010). Peningkatan Mutu Pembelajaran IPS Dengan Model Learning Community di SD Muhammadiyah Sagan Yogyakarta. Jurnal Sosialita. 2 (2).

Arikunto, S. (2016). Dasar Dasar Evaluasi Pendidikan. Jakarta. Bumi Aksara.

Nieveen, N. (1999). Prototyping to Reach Product Quality. Dalam Plomp, T Nieveen, N Gustafson, K; Branch, R.M dan van den Akker, J (eds). Design Approaches and Tools in Education and Training. London Kluwer Academic Publisher.

Rahmanadji, Didiek. (2011). Sejarah, Teori, Jenis, dan Fungsi Humor. Malang. Seni dan Desain Fakultas Sastra Universitas Negeri Malang

Ridwan. (2010). Skala Pengukuran Variabel-Variabel Penelitian. Bandung. Alfabeta.

Sudjana, N \& Rivai, A. (2007). Media Pembelajaran. Bandung. sinar baru Algesindo.

Sugiyono. (2010). Metode Penelitian Pendidikan. Bandung. Alfabeta

Suherman, Yuyus. (2009). Pengembangan Media Pembelajaran. Bandung. Diklat Profesi Guru PLB Wilayah X Jawa Barat

Triyanto. (2010). Modifikasi Pembelajaran Statistika Melalui Pendekatan Kontekstual Dengan Sentuhan Humor. Klaten. Universitas Sebelas Maret Surakarta

Widoyoko. (2012). Teknik Penyusunan Instrumen Penelitian. Yogyakarta. Pustaka Belajar.

Wiratmojo, P \& Sasonohardjo. (2002). Media Pembelajaran Bahan Ajar Diklat Kewidyaiswaraan Berjenjang Tingkat Pertama, Lembaga Administrasi Negara.

\begin{tabular}{|l|l|}
\hline Fathur Rahman & $\begin{array}{l}\text { Mahasiswa Jurusan Biologi, FMIPA, Universitas Negeri } \\
\text { Makassar } \\
\text { Email: fathurrahman1994@gmail.com }\end{array}$ \\
\hline Nurhayati, B & $\begin{array}{l}\text { MP.d, Dr, Profesor. Dosen Jurusan Biologi, FMIPA, Universitas } \\
\text { Negeri Makassar } \\
\text { Email: } \underline{\text { nurhayati.b@unm.ac.id }}\end{array}$ \\
\hline Rachmawaty & $\begin{array}{l}\text { S.Si, M.Si, Ph.D. Dosen Jurusan Biologi, FMIPA, Universitas } \\
\text { Negeri Makassar } \\
\text { Email: rachmawaty@unm.ac.id }\end{array}$ \\
\hline
\end{tabular}

